\title{
Conducting a Pricing Transactional Assessment, Integrating Cluster and Segments Analyses, To Leverage the Customer Profitability
}

\author{
Machado, Diogo ${ }^{1}$, Fernandes, Rui ${ }^{2}$ \\ ${ }^{1,2}$ Porto Accounting and Business School
}

\begin{abstract}
The profitability set per customer of a given organization implies several challenges, from the calculation of the net pricing to the development of a cost allocation system within the company's main processes. Thus, the work proposed aims at exploring the potential of a customer evaluation methodology, using pricing techniques as a supporting tool, where the analysis of customer clusters will be done. We aim to identify profitability patterns, according to the customer's supply chain role, the dimension and the potential of the business, the types of transactions frame that are established, as well as the relative effects of each cluster own characteristics in the overall business relationship. After developing the methodology, the customer profitability analysis will be performed and recommendations will be set, highlighting and quantifying the possible improvements in the contribution. The use of leveraging techniques by the average and sensitivity analysis will support the recommendations. These insights will drive the companies in their pricing decisions also as shifting their focus towards attracting and retaining the customers from the more profitable clusters.
\end{abstract}

KEYWORDS: Pricing, Customer, Profitability, Focus.

Subject classification codes: M210

\section{INTRODUCTION}

Most of the companies are focused on assessing the profitability of their products, developing techniques, but most are far behind in assessing their customers' profitability (Epstein, Friedl, \& Yuthas, 2008). Product or service quality, staff quality, corporate image, and price perception affect the customers choices. These variables are lead the organization resources with different intensities; as such, it is essential that the companies define the customers to whom more resource should be allocate and those who don't (Albalaki, 2018; Noone \& Griffin, 1998; Erjavec, Tanja \& Povalej, 2016). Once the customer profitability analysis is done, the company will understand why certain customers are more or less profitable, and those conclusions are appliable at the strategic level, guiding decisions from grow initiatives to marketplace segmentation and, at tactical level, with tactical improvements in profitability (Johnson, Simonetto, Meehan, \& Singh, 2009).

\section{CUSTOMER PROFITABILITY MEASUREMENT}

Most management accounting systems focus not on the customer but on products, departments, or geographic regions (Gupta, Foster \& Sjoblom, 1996). To Stubing (2019), the basic definition of customer's profitability is "the direct revenue from sales to the customer minus the direct expenses of providing the customer the product or service", so, the calculation of the customer profitability is pretty straightforward in Miller (2008) opinion, the revenues and costs are allocated to customers or customers segments and it's done. In the other hand, Mulhern (1999) refers that, although measuring customer profitability may looks a straightforward process, it is a quite complex task to do, as the profitability depends not only on the unit cost of a product or service, but also on the range of the services required, including marketing, distribution, and customer service (Gupta, Foster \& Sjoblom, 1996).

Because customers have different characteristics, it is important to segment them. As Wu, J. and Zheng, L. (2005) refers, customer segmentation is classifying the customers attributes as their value, revenues, preference and other factors related to strategy options and the business model frame. The traditional customer segmentation models based on demographic, attitudinal, and psychographic attributes of a customer have low accuracy, so companies should use a customer segmentation model based on customer transaction and behavioural data (Lee, \& Park, 2005). According to Mulhern (1999), firms often prefer a customer aggregation instead of individual measurement. The same author argue that companies often aggregate customers types (e.g., corporate versus consumer, retailers versus wholesalers), because it's more practical (e.g. when individual level marketing is not feasible or when individual purchase data are not available), especially when the amount of individual purchase is low. With customer aggregation, it becomes easier for companies to assign some indirect costs to the group or cluester. If the company wants to read and analyse 


\section{Customer Profitability"}

an individual/cluster customer profitability, it must implement a different accounting approach. In fact, several authors agree that the activity based cost (ABC) system provide accurate information about the costs of activities and business processes, individual products, services and customers, therefore customer profitability measurement fits better in an activity-based cost logic than in traditional cost systems (Kaplan \& Cooper, 1998; Raaij, Vernooij, \& Triest, 2003; Lahutta \& Wroński, 2014), that are more oriented to product costs and do not identify, for example, how a customer service affect the cost structures (Guerreiro, Bio, \& Merschmann, 2008). Using ABC it is recognizing that not all costs can be assigned to customers, because customers aren't directly responsible for all the activities costs, for example: the cost of auditing accounts; then that cost should not be assigned to them, so the cost is non-attributable and therefore should not be included in the customer calculation (Noone \& Griffin, 1998; Kaplan \& Cooper, 1998). Noone and Griffin (1998) referred that $\mathrm{ABC}$ is a basic concept, the premise underlying $\mathrm{ABC}$ is that the cost objects, like customers, use activities in the organization that are based on resources that incur in costs. The basic difference between traditional costs systems and ABC, as explained by Cooper \& Kaplan (1991), is that the traditional cost systems use transactional direct basis, like direct labour and machine hours to distribute the indirect costs to the products; instead, $\mathrm{ABC}$ split the indirect resources by activities.

According to Cooper \& Kaplan (1991) managers need to understand patterns of costs at the micro level, because it's impossible to management control expenses at the macro level, if they do it, they will misinterpret results. The possible mistake in the analysis is that the costs depend on produced units, but the resources used by each batch and supporting activities do not vary at a unit level.

\section{CUSTOMER PROFITABILITY ANALYSIS (CPA)}

According to Mulhern (1999), customer profitability analysis is defined as the quantified evaluation of the profitability among customers. Customer profitability analysis is also defined as a mechanism for the allocation of revenues and costs to customer segments or individual customers, allowing the profitability calculation (Raaij, Vernooij, \& Triest, 2003).

We can find out differences between several authors about which department owns the accountability of customer profitability analysis. Cardoş and Cardoş (2014) assume that customer profitability analysis is considered as a marketing topic, despite being a management accounting innovation.; on the other hand, Miller (2008) considers that, despite the marketing, sales and operations departments being the major users of CPA information, the finance department is in the best position to understand and calculate the customer's profitability.

Customer profitability analysis allows organizations to identify and understand its sources of revenues, expenses, and, in consequence, the source of profits and take actions based on customers profitability perspective, instead of a simple revenue analysis approach (Albalaki, 2018; Shapiro, Rangan, Mariarty, \& Ross, 1987; Cokins, 2015).

We now know that customers have different levels of profitability according to their characteristics, but levels of profitability will vary due to the use of different estimation methods (McManaus \& Guilding, 2008; Albalaki, 2018).

Johnson et al., (2009) presents a CPA approach as "pocket margin" perspective, calculating the profitability of each transaction by subtracting all the costs related to a singular transaction. As they defend, these costs can range from invoice discounts and promotions, to the less obviously ones, like freight costs, warehousing and other activities that may be classifies as overhead cost.

Once the profitability is measured for each customer or customer segment, Elias and Hill (2010) suggest plotting the results into a profit graph, as a whale curve, where the Yaxis of the graph shows cumulative customers or customer segment ranked and from high to low in terms of profitability from all customers and the $\mathrm{X}$-axis shows cumulative customer or customer segment ranked from high to low in terms of profitability. Usually, the conclusions will show that a low number of customers are responsible for more than $100 \%$ of the profits and, the remain customers, are normally on breakeven or even generating losses (Kaplan \& Cooper, 1998).

To conclude the CPA process, Brown (2010) proposes a four box model to segment customers based on their profitability and their relevance to the business strategy, suggesting specific actions to be addressed to each segment. For strategic and profitable customers, the company should retain them and increase their business if possible. For strategic and loss makers the action to take is to transform these customers into profitable or, at worst, move them to breakeven. On the non-strategic and profitable customers, the orders and service levels should be regularly monitored to avoid them becoming non-profitable customers. The nonstrategic and loss makers customers sales volumes and contribution needs to be solved, with increasing of selling prices or with less efforts spend developing these customers, in order to move them to the monitor box.

\section{PRICING}

Price of trade determined by an organization is usually the reflex of its competitive position and corporate view of market opportunities (Braithwaite \& Samakh, 1998). Marn et al. (2004) presents a price management with three levels:

- Industry strategy: Consider the overall industry price levels, the focus goes to demand, supply, regulation, costs, competition, and other related. It's hard to a single unit move the prices because its influence over the products and services depends on market share, and 


\section{"Conducting a Pricing Transactional Assessment, Integrating Cluster and Segments Analyses, To Leverage the Customer Profitability"}

industry characteristics (Ponikvar, Nina \& Rant, Melita, 2007);

- Product/market strategy: where the price position is compared to competitors. At this level the definition of a price level is done to optimize the customer price/benefit trade-off; and

- Transaction: is the main focus of this work, tries to define the exact price for each customer transaction with the help of pricing tools as discounts, allowances, payment terms and volume bonuses.

When a company aims to serve all customers with a single price, or a mark-up (for retailers and distributers), is driven to make large trade-offs between volume and margin. According to Nagle, et al. (2011), companies should have different prices according the segment, in order to maximize revenues and profits. At the transactional level is where pricing projects are executed, mainly because executives concentrate management energy on either the standard portfolio price list or on the invoicing pricing and discounts, failing the management of all the components that contribute to the final transaction price, resulting in a widely range of executed price (Bodea, \& Ferguson, 2014; Marn et al., 2004). As Marn and Rosiello (1992) state, the goal of transaction price management is to accomplish the best net price for each transaction. To them, the necessary steps to capture transaction prices opportunities are:

- $\quad$ To manage the pocket price band: The entire pricing should be managed to the realization of net price (or pocket price) rather than invoice price or list price;
- $\quad$ engineering the price waterfall: Executives shouldn't be at all surprised if customers or customers segments value differently each set of price waterfall, the sales representative should be able to identify the sensibility of each customer to each set; and

- getting organizational involvement and incentives: Managers who set specific goals for transaction price improvement and monitor those goals through a regular and concise transaction price performance report, are likely to improve transactions price.

\section{CASE STUDY}

This case was conducted in a subsidiary of one of the largest Portuguese multinational company that operates in the industry of production and transformation of raw materials, being the world leader in its sector. We will change the original data to protect the company against the disclosure of sensitive business information.

\subsection{Summary}

After collecting all the transactional data and all relevant costs, we start the study with a general analysis at the company. At the date of the study, the subsidiary analysed was facing profitability problems, with around 400 customers divided into three clusters (retailers, wholesalers, and others) and 700 different products.

\section{Customer individual analysis}

The customer analysis was made in a transactional basis and do not considers administrative costs, because no reliable method has been found to allocate them. As we show in Figure 1, most of the customers have a positive contribution margin. The company's customers profitability behaviour seems to behave like the "whale curve" graph presented in Elias and Hill (2010) work.

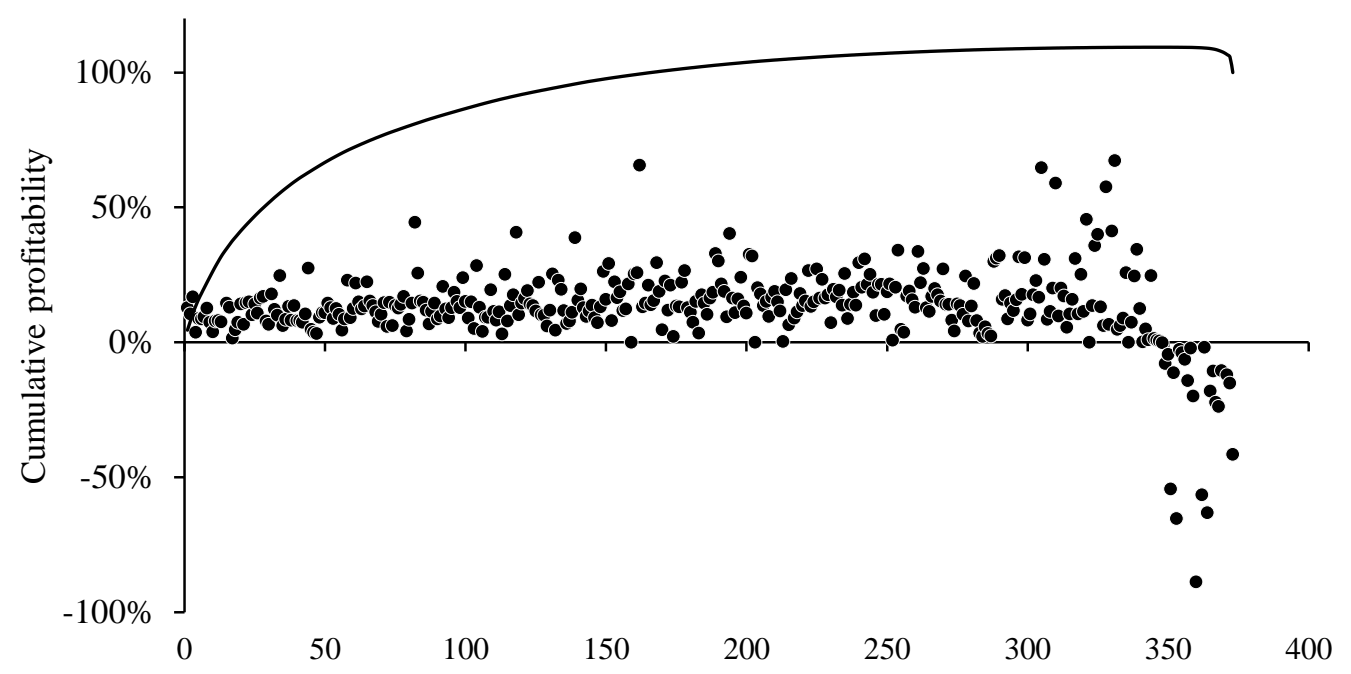

Total customers

Figure 1 - Contribution margin per customer Source: Own elaboration 


\section{"Conducting a Pricing Transactional Assessment, Integrating Cluster and Segments Analyses, To Leverage the Customer Profitability"}

In the Figure 1, where each point represents a customer, we figure out that a minority of customers (around 6,5\% of total customers) causes a loss of $9,1 \%$ of the maximum cumulative profitability. Without them the contribution margin would be around $10 \%$ higher. On the other hand, around $80 \%$ of total profitability was concentrated in 80 customers, $20 \%$ of the total customers.

Table 1 - Top/Bottom 3 customers

\begin{tabular}{|c|c|c|}
\hline $\begin{array}{l}\text { Top/Bottom } 3 \\
\text { customers }\end{array}$ & $\begin{array}{l}\text { Gross Sales (\% } \\
\text { of total) }\end{array}$ & $\begin{array}{l}\text { Contribution Margin } \\
\text { (\% of total) }\end{array}$ \\
\hline Profit maker 1 & $2,70 \%$ & $4,50 \%$ \\
\hline Profit maker 2 & $2,40 \%$ & $3,20 \%$ \\
\hline Profit maker 3 & $1,50 \%$ & $3,15 \%$ \\
\hline Loss maker 3 & $0,40 \%$ & $-0,70 \%$ \\
\hline Loss maker 2 & $0,50 \%$ & $-0,90 \%$ \\
\hline Loss maker 1 & $1,00 \%$ & $-5,72 \%$ \\
\hline
\end{tabular}

Source: Own elaboration

We look at the top three profit/loss makers and conclude that one customer represents a 5,72\% loss in contribution margin. In the side of the profits, one customer represents $4,5 \%$ of total contribution margin. After Loss makers transactional data analysis based on individual profitability waterfall, we find out that:

- The Loss maker 1 negative contribution margin was due to three products claims,

- The Loss maker 2 negative contribution margin was due to excessive commercial discounts, and

- The Loss maker 3 negative contribution margin was due to high cost of service.

At the profit makers transactions analysis, we conclude that the main cause of their superior contribution margin was result of purchase of products with above-average profitability and low cost of service.

\subsection{Segmentation}

The segmentation was made in two different perspectives:

- Profit comparability; and

- Business strategy.

In profit comparability perspective the criteria adopted was the position of the customer in the supply chain row. As we have been already said, the company's traditional segments are:

- $\quad$ Retailers - The ones who sell to the final customer;
- Wholesalers - Distributors or intermediaries; and

- Others - All categories not applicable above.

At the strategic view, the customers were classified accordingly to their actual or expected sales representativeness.

- A classification - Clients with large impact or expected representativeness of gross sales $(\geq 10 \%)$;

- B classification - Clients with solid impact or expected representativeness of gross sales $(\geq 5 \% \&<10 \%)$;

- C classification - Clients with regular impact or expected representativeness of gross sales $(\geq 2,5 \%$ \& $<5 \%)$

- D classification - Clients with residual impact or expected representativeness of gross sales $(<2,5 \%)$; and

- E classification - One time customers.

\subsection{Traditional clusters analysis}

Retailers have a 3\% contribution margin and the wholesalers' total costs are $8 \%$ higher than gross sales, that means an $8 \%$ loss in this segment. The most relevant differences between both clusters' costs are commercial discounts and cost of service. Before going through costs' analysis, we will perceive what is the position of customers on gross sales that generate more or less profit. 


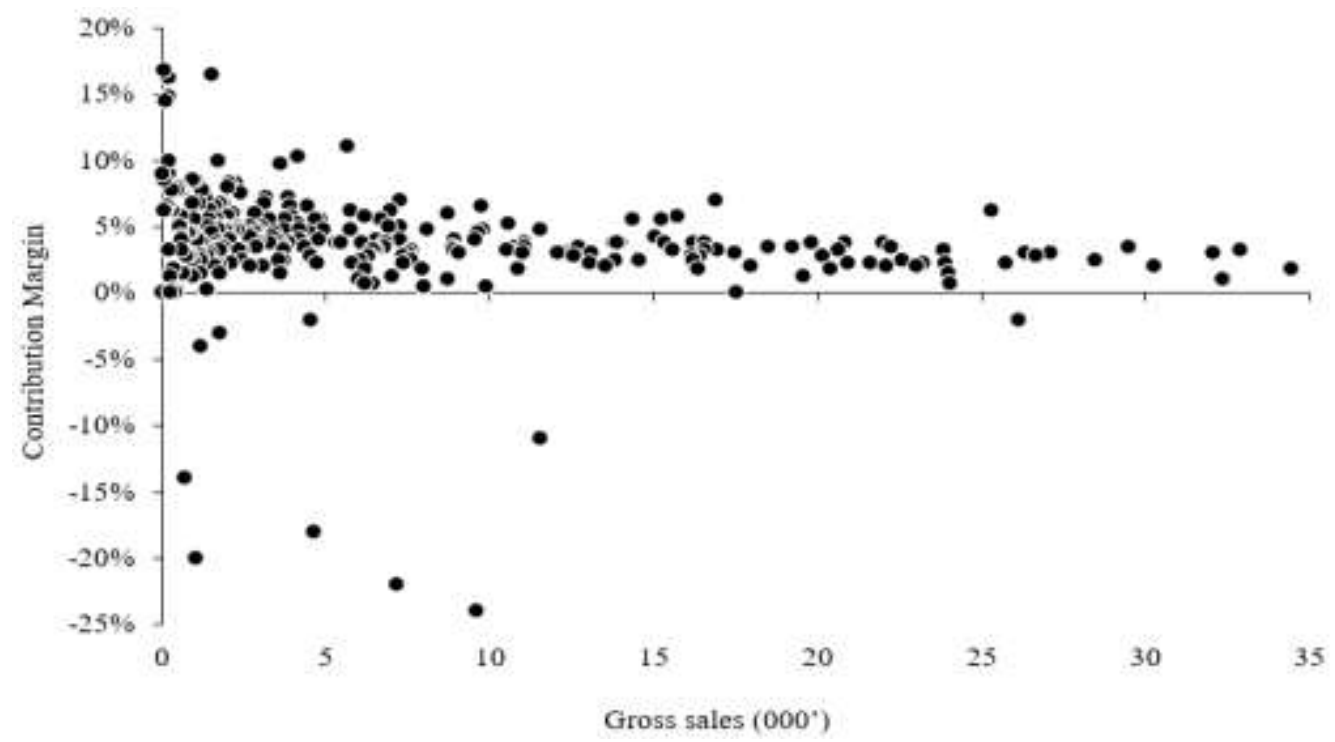

Figure 2 - Gross sales Vs. Contribution margin representation

Source: Own elaboration

We have computed each customer profitability and gross sales from both clusters into one graph, represented on Plate 1. We noticed a bunch of customers that have some negative influence on the average because of their sales representativeness, despite being all with gross sales under 30 000. Plate 1 shows a pattern of decreasing margin as gross sales increase. We identified at wholesaler's analysis that one customer has a relatively high influence on the cluster weighted average margin of $-8 \%$. The retailer's analysis shown a large gap between multiple customers profitability, that should not be happening because they're on the same position at supply chain row.

\subsection{Commercial discounts}

The commercial discounts have the largest representativeness of gross sales, for both segments. The analysis will be done comparing commercial discounts with the supposed discount to that sales volume, defined as the company standards. The retailers have a lower commercial discount than wholesalers, mainly because of their position in the supply chain.

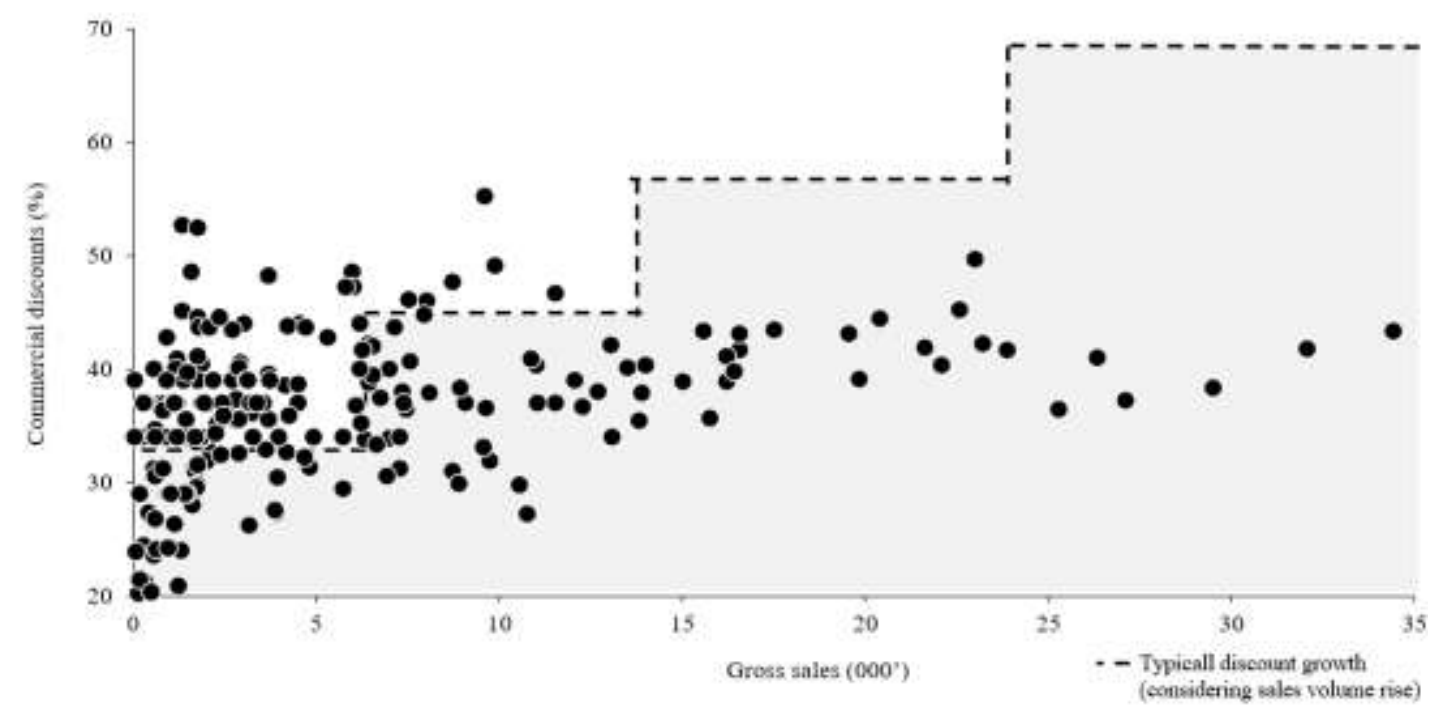

Figure 3 - Commercial discounts applied Vs. Potential incentives by sales volume Source: Own elaboration

As we can figure out, there are a lot of customers out of the "stairs", that means the commercial discounts policies are not being accomplished in the lower sales. In the other side, customers with higher gross sales are not enjoying the maximum discount they could have access to.

\subsection{Cost of service}

The cost of service is composed by marketing costs, logistic costs, and distribution costs. The most relevant cost here is the distribution cost with a $9 \%$ representation of gross sales consumption. Marketing and logistic costs are, in part, distributed with subjective criteria. So, to resume the analysis 
at the most direct and effective cost, marketing and logistic costs will be excluded of analysis. The analysis was made in a transaction basis, comparing the cost driver (quantity) of distribution costs. If the analysis was made in a gross sales

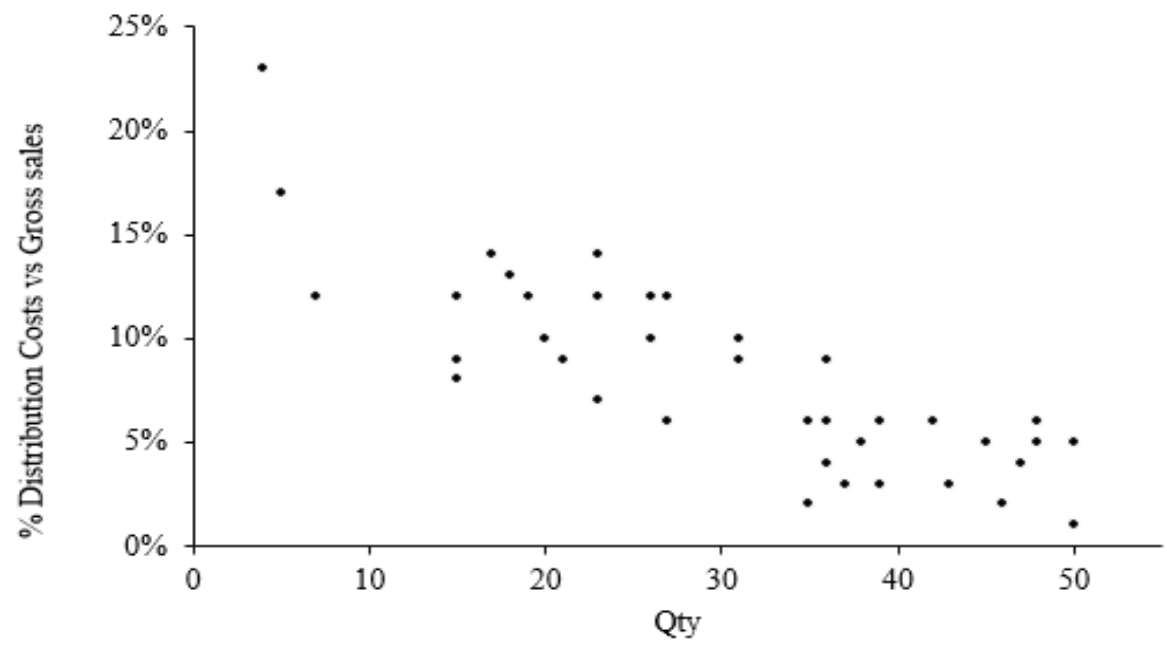

Figure 4 - Distribution cost Vs. Gross sales transaction analysis Source: Own elaboration

There are multiple transactions with zero costs (not shown in Plate 3), it is the policy of the company to not surcharge the distribution costs of clients with A and B classification. The transactions in the Plate 3 reveal a pattern along the quantity axe, as the quantity increases the relative distribution cost decreases. As result of customer classification, more efforts are made to please the customer. That policy can be quite expensive to the company, as Plate 3 shows, low quantity orders and distribution costs consuming $15-25 \%$ of gross sales.

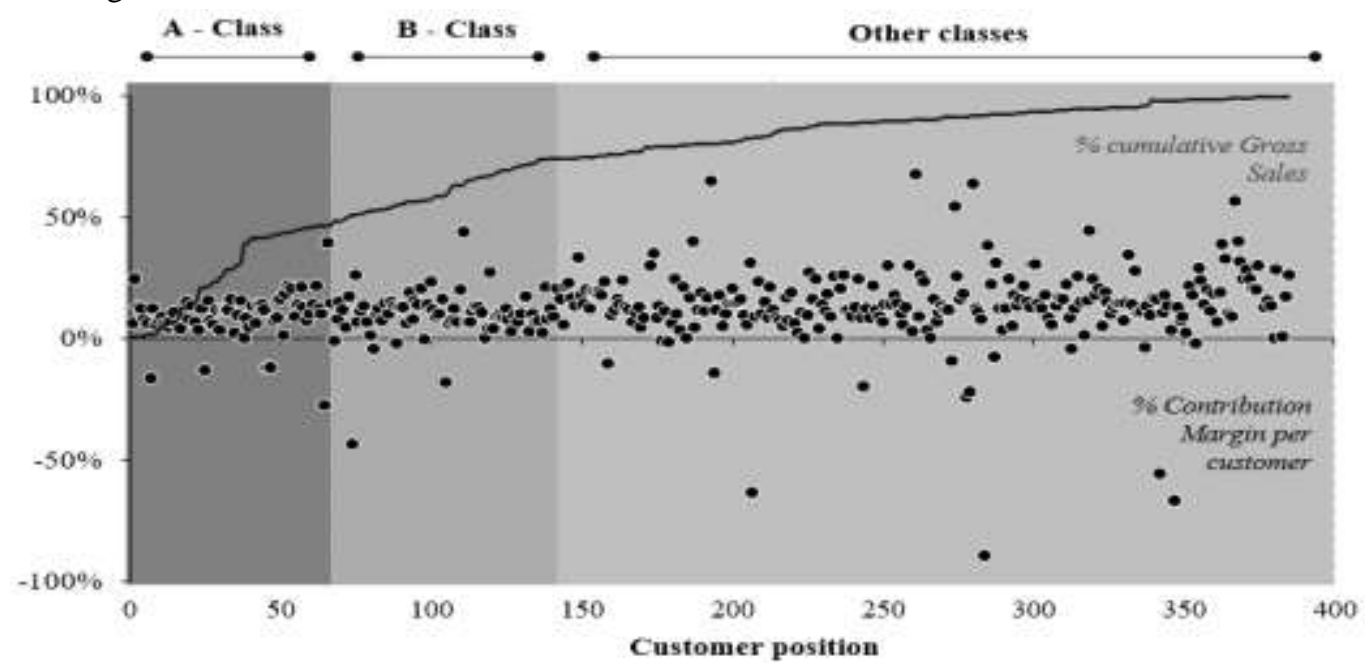

Figure 5 - Customer profitability by classification
Source: Own elaboration

There are more negative contributors in customers classified in the "Other classes" range, because they are low sales value customers, so any extra cost could mean a larger contribution cost variation. The main problems are the negative customers classified as A and B; they are making the company losing volume perspective instead of quantity perspective, or in a customer global analysis instead transactional based, the cause of high distribution costs (frequency of interactions and units volume) would remain unknown.

\subsection{Strategic actions}

In this section we will apply the 4 box model proposed by Brown (2010), using the information collected at the previous analysis as guide to price and policies fixation. In the company strategic view, the company distinguishes customers by classification, as mentioned in segmentation section.

money. The application of the 4 box model will determine the actions to take to reverse unprofitable situations. To apply the model correctly, we need first to define the strategic customers and unprofitable customers:

- Strategic customers: Customers classified as A, B and $\mathrm{C}$; 


\section{"Conducting a Pricing Transactional Assessment, Integrating Cluster and Segments Analyses, To Leverage the Customer Profitability"}

- Non-strategic customers: All the other customers; and

- Unprofitable customers: Customers with contribution margin $<0 \%$.

- Unprofitable and strategic customers

It is the most important analysis, because customers are unprofitable and, at the same time, we want to do business with them. To improve the relation between the company and their customers, Brown (2010) proposes to transform them into profit or, at worst, move them to breakeven. There are a few customers in this type of situation, an individual analysis for each one is deserved. If customers get level customers with above average distribution costs to the average distribution costs lead at $4 \%$ gain in contribution margin.

- Profitable and strategic customers

The company should retain this type of customer and increase the business as possible (Brown, 2010). To successfully accomplish the task of retaining and increasing their business, we recommend the following actions:

- Reinforce the communications with the customers, visiting or calling them more frequently;

- Reinforce service level provided, with focus on the marketing communication to also attract new customers; and

- Explore all the client potential, if necessary, using commercial discounts as tool to incentivize the customer to increase sales, always on the preestablished limits.

The recommendations above will positively affect the contribution margin.

- Unprofitable and non-strategic customers

At non-strategic and profitable customers, the sales volumes and contribution needs to be replaced, rather with increasing
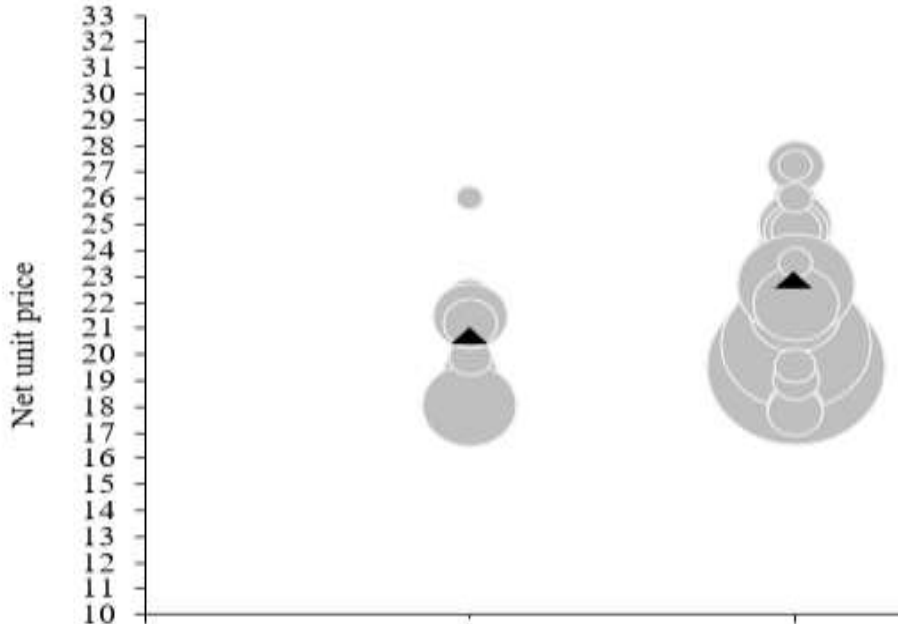

Wholesalers

Product number 1

Average gross sales

Customers

(circle area represents gross sales volume)

Figure 6 - Product number 1 transactions by cluster

Source: Own elaboration

Retailers

of selling prices or decreasing the efforts spent developing these customers (Brown, 2010). This type of customer has more pragmatic recommendations because they are out of the company focus, as follows:

- Identify customers with lower volume of sales and review their discount conditions;

- Adapt to a less costly service;

- Analyse the items portfolio, driving their sales to more profitable items;

- Assessing and deciding whether to continue or stop selling unprofitable items, if they exist; and

- Assess and decide whether to serve or stop serving these customers.

The non-strategic and profitable customers are easy to work on. If the company pretends to have business relations with non-strategic customers, it's because the gains are sufficiently attractive and useful. The gains with the negative clients should be brought to the average.

- $\quad$ Profitable and non-strategic customers

At these customers the orders and service levels should be regularly monitored to ensure nothing changes that causes them to become non-profitable customers (Brown, 2010). Although these customers are not strategic, they give a positive contribute to the organization, so we prefer to adopt the recommendations of "Profitable and strategic customers", although, in a conservative way, because the focus should be on strategic customers.

- Traditional segments

The recommendations at traditional segments are in a anomaly corrections perspective. One useful tool to do that is comparing clusters at most relevant products and find possible inconsistencies.

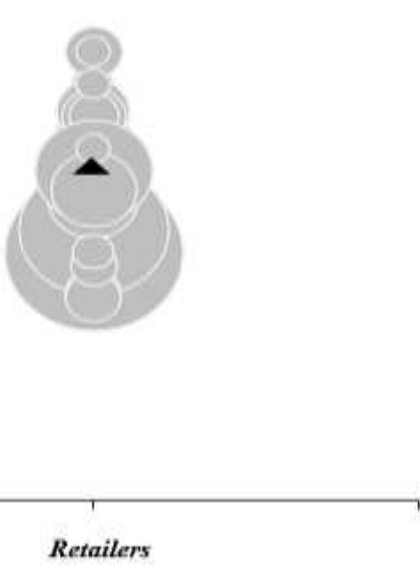




\section{"Conducting a Pricing Transactional Assessment, Integrating Cluster and Segments Analyses, To Leverage the Customer Profitability"}

We selected a product for the analysis, as Plate 5 shows, retailers have a higher net unit price average, indicating that wholesalers are getting more discounts than retailers, as expected. The bigger the bubble, the lower the net unit price, because the discounts are mostly applied at customers with larger sales. We noticed through Plate 5 that are some smaller circles with a net price below the average, to that customers there is no reason to have that kind of special net unit price, the company should move them to an upper net unit price. For the customers with lower net sales but with an interesting sales volume, the company should try to move them to the average. With this type of analysis, we get a way to pricing every customer and ensuring the fair price for them.

In Table II, we resume the actions to take, the basis of an action plan used to implement the methodology, with defined accountabilities and the time to do it.

Table 2 - Action recommendations summary

\begin{tabular}{|c|c|c|}
\hline Segment & Actions & $\begin{array}{l}\text { Expected impact } \% \\
\text { contribution margin }\end{array}$ \\
\hline $\begin{array}{l}\text { Unprofitable and strategic } \\
\text { customers }\end{array}$ & $\begin{array}{l}\text { Implement a more effective audit process on } \\
\text { products load and discharge }\end{array}$ & $5 \%$ \\
\hline $\begin{array}{l}\text { Unprofitable and strategic } \\
\text { customers }\end{array}$ & $\begin{array}{l}\text { Create exceptions on customers' discount } \\
\text { agreements regarding products with high claims }\end{array}$ & $7 \%$ \\
\hline $\begin{array}{l}\text { Unprofitable and strategic } \\
\text { customers }\end{array}$ & Correctly execute commercial discounts policies & $27 \%$ \\
\hline $\begin{array}{l}\text { Unprofitable and strategic } \\
\text { customers }\end{array}$ & $\begin{array}{l}\text { Level the customers with above average distribution } \\
\text { costs to the average distribution costs }\end{array}$ & $4 \%$ \\
\hline $\begin{array}{l}\text { Unprofitable and strategic } \\
\text { customers }\end{array}$ & Fixate a minimum quantity with free charges & $2 \%$ \\
\hline $\begin{array}{l}\text { Unprofitable and non- } \\
\text { strategic customers }\end{array}$ & $\begin{array}{l}\text { Identify customers with lower volume of sales and } \\
\text { review their discount conditions }\end{array}$ & $10 \%$ \\
\hline $\begin{array}{l}\text { Unprofitable and non- } \\
\text { strategic customers }\end{array}$ & $\begin{array}{l}\text { Analyze the mix of items purchased, redirecting their } \\
\text { sales to more profitable items }\end{array}$ & $2 \%$ \\
\hline $\begin{array}{l}\text { Unprofitable and non- } \\
\text { strategic customers }\end{array}$ & Stop serving recurrent unprofitable customers & $4 \%$ \\
\hline $\begin{array}{l}\text { Unprofitable and non- } \\
\text { strategic customers }\end{array}$ & Stop selling them unprofitable items & $1 \%$ \\
\hline Traditional segments & $\begin{array}{l}\text { Move small sales customers with lower net price than } \\
\text { average to their fair position }\end{array}$ & $15 \%$ \\
\hline Traditional segments & $\begin{array}{l}\text { Move to average all customers with lower net unit } \\
\text { price and higher average sales volume }\end{array}$ & $35 \%$ \\
\hline
\end{tabular}

Source: Own elaboration

The gains are individual and not cumulative. Most of the gains are in the traditional segment analysis, it's because they have a general recommendation that covers a part of the remaining recommendations. The traditional segments analysis is fine to identify abnormal situations in individual customers and using the remain analysis, in an individual base, to identify the causes of each abnormal situation and act on it. The remaining recommendations are the most appropriated to integrate into the company strategy, acting not accordingly to the most profitable action at the time but accordingly to the company strategy, evens if it means lose money now, with the expectation of future return.

\section{CONCLUSION}

The analysis proposed was effective to identify the causes of unprofitable customers and focus on general profits. In this case study, the profitability patterns have been identified using pricing tools. The pricing components, as the net pricing and commercial discounts, have been analysed to improve the relationship between the company and the customers, with the focus on the strategic ones. The segmentation and cluster frame allowed a deeper analysis leading to the identification and quantification of potential gains. The high potential customers are the most sensible ones in the analysis, revealing some abnormal profitability trends because of their role in the commercial and marketing departments. The analysis efforts need to be coordinated with those departments and a common reading need to be set for the effectiveness of the recommendations.

The successfully implementation of the analysis recommendations depends on the objectives proposed to all the responsible for taking the actions; the actions need to be 


\section{Customer Profitability"}

clear showing the potential gains and need to be followed on periodically reports.

The case study involved 2 sessions with the head of commercial and marketing department, one for preparing and validating the assumptions and the global outlook and the final one to discuss the recommendations. Overall, the reaction was very positive with this methodology and the actions list has been validated and allocated for follow up.

\section{REFERENCES}

1. Albalaki, Faeq. (2018). Customer Profitability Analysis, Cost System Purposes and Decision Making Process: A Research Framework. Account and Financial Management Journal.

2. Bodea, T. \& Ferguson, Mark. (2014). Segmentation, revenue management, and pricing analytics. Segmentation, Revenue Management and Pricing Analytics. 1-256. 10.4324/9780203802151.

3. Braithwaite, A. and Samakh, E. (1998), "The costto-serve method", International Journal of Logistics Management 9(1):69-84.

DOI: $10.1108 / 09574099810805753$

4. Brown, L. (2010). Customer profitability analysis. Profit Analytics Ltd.

5. Cardoş, I. R., \& Cardos, V. D. (2014). Measuring customer profitability with activity-based costing and balanced scorecard. Annales Universitatis Apulensis-Series Oeconomica -

https://ideas.repec.org/a/alu/journl/v1y2014i16p5.h tml

6. Cokins, G. (2015). Measuring and managing customer profitability. Strategic Finance, 96(8), 2327.

7. Cooper, R., \& Kaplan, R. S. (May-June of 1991). Profit priorities from Activity-Based Costing. Harvard Business Review, pp. 130-135.

8. Elias, N., \& Hill, D. (2010). Customer profitability management. Montvale: Institute of Management Accountants.

9. Epstein, M. J., M. Friedl and K. Yuthas. 2008. Managing customer profitability. Journal of Accountancy (December): 54-60.

10. Erjavec, Hana \& Dmitrovic, Tanja \& Povalej, Petra. (2016). Drivers of customer satisfaction and loyalty in service industries. Journal of Business Economics and Management. 17. 810-823. 10.3846/16111699.2013.860614.

11. Foster, G., Gupta, M., \& Sjoblom, L. (1996). Customer Profitability Analysis: Challenges and New Directions. Journal of Cost Management, 10 (Spring), 5- 17.

12. Guerreiro, Reinaldo \& Bio, Sérgio \& Merschmann, Elvira. (2008). Cost-to-serve measurement and customer profitability analysis. International Journal of Logistics Management, The. 19. 389-407.

13. Lahutta, Dawid \& Wroński, Paweł. (2014). The influence of the Cost-to-Serve methodology on customer profitability. Prace Naukowe Uniwersytetu Ekonomicznego we Wrocławiu.

14. Lee, J. H., \& Park, S. C. (2005). Intelligent profitable customers segmentation system based on business intelligence tools. Expert Systems with Applications, 29, 145-152

15. Johnson, E., Simonetto, M., Meehan, J., \& Singh, R. (2009). How profitable are your customers... really? (D. D. LLC, Ed.) Delloit Review Issue 5, pp. 5-15.

16. Kaplan, R.S, and Cooper, R. (1998), Cost and Effect: Using Integrated Cost System to Drive Profitability, Harvard Business School Press, Boston, MA

17. Marn, M., \& Rosiello, R.L. (1992). Managing price, gaining profit. Harvard business review, 70 5, 84-94.

18. Marn, M., Roegner, E., \& Zawada, C.C. (2004). The Price Advantage.

19. McManus, L., \& Guilding, C. (2008). Exploring the potential of customer accounting: a synthesis of the accounting and marketing literatures. Journal of Marketing Management.

20. Miller, John A. (2008), "Customer Profitability", Wiley InterScience, (5/6): 63-68, doi: $10.1002 /$ jcaf.20404.

21. Mulhern, Francis J. (1999). "Customer profitability analysis: measurement, concentration, and research directions", Journal of Interactive Marketing, 13 (1): 25-40.

22. Nagle, T. T., Hogan, J. E., \& Zale, J. (2011). The strategy and tactics of pricing: A guide to growing more profitably.

23. Noone, Breffni e Griffin, Peter (1998). Development of an Activity-based Customer

24. Ponikvar, Nina \& Rant, Melita. (2007). Firm specific determinants of markup - the case of Slovenian manufacturing firms. Journal of Business Economics and Management. 8. 203-212. 10.3846/16111699.2007.9636170.

25. Profitability System for Yield Management, Faculty of Tourism and Food, Dublin Institute of Technology, Res. 4, 279-292.

26. Shapiro, B. P., Rangan, V. K., Moriarty, R. T., \& Ross, E. B. (1987). Manage customers for profits (not just sales). Harvard Business Review, 65(5), 101-108

27. Stubing, David P., (2019). Measuring and managing customer profitability: Implications for identifying and managing unprofitable customers. College of Business Theses and Dissertations. 8. 
"Conducting a Pricing Transactional Assessment, Integrating Cluster and Segments Analyses, To Leverage the Customer Profitability"

28. Van Raaij E., Vernooij M. J. A., van Triest S., 2003. The implementation of customer profitability analysis: a case study, Industrial Marketing Management, 32, pp. 573-583

29. Wu, J. and Zheng, L. 2005. "Research on customer segmentation model by clustering". In ETechnology, e-Commerce and e-Service, 2005. EEE '05. Proceeding, v- xiv from the 2005 IEEE International Conference Hong Kong 29 March-1 April 2005 